\title{
NETWORK AND INNOVATION AT THE BRAZILIAN AGRICULTURAL RESEARCH CORPORATION
}

\begin{abstract}
Brazil is a major producer of food, fiber and renewable energy, having great importance for the world's food security. The country has substantially invested in Research, Development and Innovation (RD\&I) in the last four decades and the Brazilian Agricultural Research Corporation (Embrapa) has been coordinating this effort. This study aimed to explore the association between centrality measures for research networking and the generation of innovations by Embrapa research centers and their partner institutions. The study analyzed patent applications from Embrapa between the years 1980 and 2009. The methodological techniques applied were social network analysis, correlation and simple linear regression. Results indicate that the greater centrality in research centers networks of Empraba were associated with higher levels of innovation. Results also evidenced the importance of networks, such as the National Agricultural Research System (SNPA, in portuguese), on generating innovation for agriculture. These findings suggest that public policies promoting agricultural innovation should be designed to strengthen collaboration among institutions and not only with individual scientists.
\end{abstract}

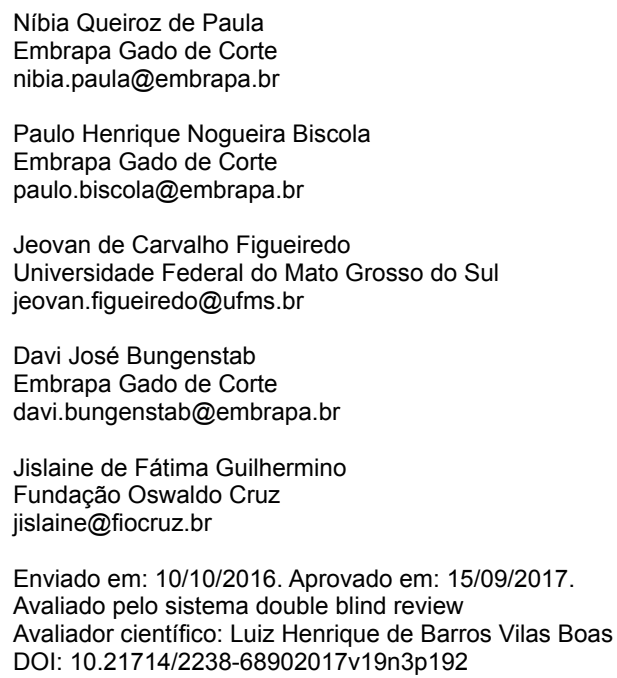

Keywords: Embrapa, Patents, Innovation, Social Network Analysis, Network Centrality.

\section{INTRODUCTION}

Brazil is a major producer and exporter of food, fiber and renewable energy, having great importance for the world's food security. The Brazilian agribusiness represents almost two thirds of the national Gross Domestic Product (GDP) (CEPEA-USP and CNA, 2012), considering the overall sum of farming, processing and inputs from manufacturing sectors.

Davis and Goldberg (1957) defined agribusiness as the sum of all production and distribution operations of agricultural supplies, farming operations, storage, processing and distribution of agricultural products as well as their produced items.

To achieve such accomplishments in agribusiness, Brazil has made important investments in Research, Development and Innovation (RD\&I) in the last four decades. The creation of the Brazilian Agricultural Research Corporation (Embrapa) was a major milestone in this process, whose work added to other incentives, led the country to substantial production increases, turning Brazil into one of the world's leaders in the sector (Gouvea and Kassicieh, 2012).

Therefore, from a broad perspective, organizations such as Embrapa are also important for the national agribusiness development because the sector constantly faces new challenges, for instance, changes on regulations, consumer preferences, new competitors, new pests and diseases among others. Thus, the knowledge from several sources is needed to deal with such changes, requiring a dense network of connections. Most of these problems cannot be solved by a single farmer, which demands changes in different segments of the value chain (The World Bank, 2006). 
Following this logic, there is an organized partnership for agricultural research in Brazil called the National Agricultural Research System (SNPA). It includes institutions such as Embrapa, the State Agricultural Research Organizations (OEPAS), universities and other organizations related to agriculture research (Cornell University et al., 2017).

Historically, the RD\&I in agriculture hve been encouraged by the Brazilian Federal Government. Recent signs of this effort are the Innovation Law, the Constitutional Amendment 85, the Agribusiness Sector Fund (CT-AGRO) and the ABC Plan (Low Carbon Emissions Agriculture). The Law No. 10973 / 2004, called Innovation Act, regulated by the Governmental Decree 5563, was created to encourage and legitimate innovation, simplifying interactions among universities, research institutions and the production sector.

Recent studies have explored the influence of collaboration in generating innovation, showing that networks have a positive effect in generating knowledge. The most recent work can be found at: Protogerou et al. (2013), Temel et al. (2013), Uddin et al. (2013), Paula (2014), Wang and Hsu (2014), Pinto et al. (2015), Shiri et al. (2015).

Considering the importance of the Brazilian agribusiness and the already existing national network of institutions focused on research and innovation for agriculture formalized as the SNPA, in which Emprapa research centers play a major role, it is very important to better understand the relationship between collaboration and accomplishing innovation. In this sense, the major goal of this work is to explore the association between social network and the generation of innovations among Embrapa research centers and its partner institutions.

However, it is important to be aware that the context of innovation is complex and varied. According to Robertson and Langlois (1995) its environment has great possibilities for efficient relationships, which there is some level of uncertainty if public policies will always be adequate for a substantial share of industries. According to the authors, attempts to implement policies could be even destructive. Therefore, improving the knowledge on how these relationships happen is essential to reduce the risks of governments deteriorate instead of improving current environments, which is another important contribution of this work in the long run.

\section{LITERATURE REVIEW}

\subsection{Innovation Networks}

Inter-organizational networks for innovation, or simply innovation networks, are complex networks of relationship between companies, universities and other research organizations associated with the generation and sharing of relevant knowledge for technological innovation (Malerba and Vonortas, 2009).

For Björk and Magnusson (2009), social networks have been recognized for their importance for improving learning and creating new knowledge. This phenomenon happens through communities that spontaneously form groups of people looking for knowledge share that promotes innovation. Thus, network analysis helps to explore the structural and relational aspects of social networks within an organization.

For Wang e Hsu (2014), the development of a relationship has a positive impact on innovation. According to the authors, relationships develop progressively when organizations learn from the interactions among themselves and commit even more enthusiastically to the relationship. During this process, partners learn about resources, strategies and business context of other sectors. In this regard, management should not concentrate only in innovation systems, but also in support learning on how to relate with partners.

An important characteristic of innovation networks is that the innovation process is interactive and systemic, which means that learning occurs by means of interactions. The ability to generate, apply and disseminate new knowledge transcends the sphere of individual companies and starts to happen through constant interaction among companies and other organizations. The formation of innovation networks can be also motivated by the desire to reduce uncertainty and complexity inherent to innovation, especially regarding factors associated with demand (Alves et al., 2004; De Pellegrin et al., 2007).

\subsection{Structural Aspects}

For Newman (2006), a network is a set of items, called vertices or nodes with connections between them called edges or lines. Structural characteristics are aggregated to the characteristics of relationships between nodes, which leads to a scenario where both structural and relational characteristics are important for network analysis.

According to Jackson (2008), the set $\mathrm{N}=\{1$, $\ldots, \mathrm{N}\}$ is a set of actors that are involved in a network of relationships. The author emphasizes that actors can be individuals, companies or other organizations. For example, Protogerou et al. (2013) found that educational institutions and research centers tend to have a more active and prominent role in the networks examined. 
Some structural characteristics have implications for network analysis, such as the actor's position in the network, what can influence the movement of assets, information and status causing asymmetry of resources. This allows some actors to acquire more competitive benefits of their relational ties in the network than others, as discussed in the next topic.

Burt (1992) stated that more central actors have higher social capital than other network members. This happens because these actors can have control over the relationships of others, taking advantage from knowing something the others do not know, besides mobilizing individuals without intervention of other actors.

Therefore, information about how an actor is central can be very important. In the same way, indications about an actor's position in a network can be helpful. The centrality, as reported by Jackson (2008), is a micro measure for comparing actors, reporting how a particular actor relates to the entire network.

To Steiner (2006), the centrality that characterizes the relative position of actors in a network increases as the actor gets a greater number of connections with other actors. Many different measures of centrality have been developed and each of them intends to identify different aspects of the concept. This work adopts two centrality measures: degree centrality and betweenness centrality. In a study addressing a similar subject, Uddin et al. (2013) identified that degree and betweenness centrality values of authors in a co-authorship network influence the performance (i.e., citation count) and formation (i.e., tie strength) of scientific collaborations.

Degree centrality means how intensely an actor is connected. The centrality measure for an individual actor refers to the actor's degree $d$ (ni), which is obtained by the number of relationships that are linked to it. The degree of an actor is a score ranging from 0 (where the actor is considered isolated) when there are no adjacent actors, and up to $n-1$, when an actor has relations with all other actors in the chart, where $n$ represents all actors in the network (Wasserman and Faust, 1994).

The degree centrality $(C D(n i))$ of an actor is obtained by the Equation 1:

$C_{D}\left(n_{i}\right)=d\left(n_{i}\right)=x_{i+}=\sum_{j} x_{i j}=\sum_{j} x_{j i}$

where,

ni represents an actor;

$d($ ni) corresponds to the actor's degree;

$n$ refers to the number of actors in a network;
$X i+i$ s the degree of an actor

$\sum x i j$ is a matrix notation, which corresponds to the degree of an actor.

For Wasserman and Faust (1994), action happens on the network in an actor with a high degree centrality. An actor with a high degree is in direct contact or adjacent to many other actors. Therefore, this actor should be recognized as a great relational information channel. In fact, this actor is a key player in the network and occupies a central location. On the other hand, if the actor is completely isolated $(d(n i)=0)$, the removal of this actor from the network has no effect on current relationships.

This measure intuitively shows how well a point is connected with its environment and it can be assumed that the corresponding agent has a central role because it is well connected and "in the thick of things" (Scott, 2017). According to Yan and Ding (2009), actors with a higher degree centrality tend to have a greater capacity to influence others.

In the studies from Abbasi et al. (2011), Eslami et al. (2013) and Guan et al. (2016), a high score on degree centrality was associated to a higher innovation activity resulting from network collaboration.

However, for Hansen, Shneiderman and Smith (2011), the degree centrality is a simple counting of the total number of connections linked to an actor and can be considered as a kind of popularity measure, being a rough measurement that does not recognize the difference between quantity and quality. The authors illustrate that this measure does not distinguish between an actor that is the president of the United States to another who is a student who dropped out school. Therefore, it is important to also present a more complex centrality measure, which is the betweenness centrality.

Betweenness Centrality is a centrality measure proposed by Freeman (1977) based on how well situated an actor is in terms of its distance to other actors. In the betweenness centrality, the actor acts as mediator among the others. Therefore, according to Wasserman and Faust (1994), an actor is central when it is among other actors in their geodesic (shortest distance that joins two actors). This implies that, to have a great betweenness centrality, the actor should be among many of the actors through their geodesics. Scott (2017) considers that betweennes centrality will eventually become the most complex centrality measures to calculate.

Wasserman and Faust (1994) found that having a large betweenness centrality allows more control over

Organizações Rurais \& Agroindustriais, Lavras, v. 19, n. 3, p. 192-203, 2017 
the flow of information, or even more control over the interactions between actors. Everett and Borgatti (2005) share the same assumption, adding that a greater degree of centrality is positively related to social capital.

For Yin et al., (2006), individuals with high betweenness centrality in a network are pivotal for knowledge flow, which is critical for the development of new products and innovative ideas. Studies by Ferriani et al. (2009), Abbasi et al. (2012) and Guan et al. (2016) found a positive influence of betweenness centrality towards a tendency to generate innovation.

The Equation 2 that calculates betweenness centrality for an actor, presented by Jackson (2008), is as follows.

$$
C e_{i}^{B}(g)=\sum_{k \neq j: i \notin\{k, j\}} \frac{P_{i}(k j) / P(k j)}{(n-1)(n-2) / 2}
$$

where,

Pi(kj) is the number of geodesics (shortest path) between $k$ and $j$;

$P(k j)$ is the total number of geodesic between $k$ and $j$;

According to Jackson (2008), the betweenness centrality takes values between 0 and 1 . The closer the betweenness centrality of actor $i$ is to 1 means that it is positioned with maximum short paths connecting $k$ and $j$; and the closer to 0 means that the actor $\mathrm{i}$ is less critical for $k$ and $j$.

Hansen et al., (2011) understand the betweenness centrality as a measure of the frequency that a particular actor is found in the shortest path between two other actors. The intermediate actor could be considered as a "bridge" that allows estimating how much the removal of this actor would break the connections among other actors in the network. This raises the concept of structural gap, which is a missing link between two actors. Wherever two or more groups cannot connect, it can be argued that there is a structural crack that is waiting to be filled.

\section{METHODOLOGY}

This is a quantitative research, where secondary data were used. The study is characterized as documental and retrospective (Marconi et al., 2003). This approach was chosen because it allows identifying patents, which has documented information, being a rich and stable database, available from official sources, which granted reliable access to information (Gil, 2002).

\subsection{Research Data}

Embrapa was selected for this study because it is responsible for coordinating the Brazilian National Agricultural Research System (SNPA) and for being considered one of the main institutions of the national innovation system in the Brazilian agribusiness, playing a key role on agricultural research in the country.

Embrapa is also known for its strong use of intellectual property protection and has served as a model for other centers on how to manage technology and technology transfer to other companies and institutions (Cornell University et al., 2017).

Embrapa, as leader of the strong SNPA network, involves its 46 research centers, each specialized in a particular topic (Correa et al., 2014). These institutional characteristics signalize the previous existence of centrality in the network to be studied.

Present in all regions of Brazil and generating knowledge and technology for tropical agriculture, Embrapa has over 9,700 employees, of which about 2,500 are researchers. Its annual budget is around 3 billion Brazilian Reais (BRL) (Embrapa, 2017).

According to the Organization for Economic Co-operation and Development [OECD] (1997), patents are fundamental S\&T indicators for measuring innovation. Thus, patent data, considering both requests and concessions, correspond to an intermediate result of innovation activity and are an indicative of the innovative capacity of a company.

Secondary data related to patents used in this research are from the National Institute of Industrial Property (INPI) database. Data were analyzed considering the inventor's name and affiliation to one of the Embrapa research centers, since the database has only Embrapa as depositor or holder and not specific centers. This happens because patent applications are carried out by a central office at Embrapa Headquarters in Brasilia-DF.

As semantic search engine for the database e-Patents from INPI, the keyword used was "Embrapa". In this way, all patent applications made by Embrapa were located, which included all patents applications already granted, under analysis, rejected, in process of forfeiture, filing and in extinction.

For network analysis, it was considered the network of actors formed by organizations that include Embrapa research centers and their partner organizations. For linking inventors to their respective Embrapa center, the Brazilian academic curriculum database from the 
National Council for Scientific and Technological Development (CNPq) named "Plataforma Lattes" was used. The inventor's affiliation to a given Embrapa research center was checked for the year the patent application was made.

By $30^{\text {th }}$ July 2013, the search found 282 patent applications for Embrapa, done between 1980 and 2009. During data processing, some data were excluded due to methodological issues, since they did not contain enough information that would be necessary for the analysis, and most of them were related to classified patent applications. After this step, a total of 222 patent applications were left for analysis. From these data, it was possible to identify 64 actors in the organizational patent network, being 30 Embrapa research centers and 34 Embrapa institutional partners. From these data, an analysis of social networks was carried out, as presented in the next topics.

\subsection{Method of Analysis for Social Networks}

An observation can be linked to another through network connections. Therefore, if there is a connection between the actors $i$ and $j$, this indicates that the actors can influence each other so that their variable attributes become similar to each other (Robins, Lewis and Wang, 2012).

The network analysis approach, according to Salmon et al., (2013), is centered on the use of networks to describe information or implied concepts of conscience and relations between the actors.

For this work, the social network analysis was performed using the free software Gephi, version 0.8.1, which enables the exploitation and manipulation of networks and graphs. Its architecture is flexible and multitasking, which allows working with complex data sets, producing valuable visual results. It also provides easy and comprehensive access to network data and enables spatialization, filtering, navigation, manipulation and grouping, enabling dynamic visualization of network. Furthermore, the software provides metric results for the measures that were used in this study, namely: number of players, number of relational ties and measures of centrality (Bastian, Heymann and Jacomy, 2009).

The degree centrality and betweenness centrality in the patent generation networks were analyzed through the Gephi software. Chart 1 summarizes the centrality measures adopted.

In addition to the centrality of the network analysis, statistical analyzes were also performed and are presented in the following section.
CHART 1 - Summary of the centrality measures

\begin{tabular}{ccc}
\hline $\begin{array}{c}\text { Centrality } \\
\text { measure }\end{array}$ & Definition & Result interval \\
\hline $\begin{array}{c}\text { Degree } \\
\text { centrality }\end{array}$ & $\begin{array}{c}\text { Number of } \\
\text { relationships that are } \\
\text { incident on an actor. }\end{array}$ & $\begin{array}{c}\text { From } 0 \text { to } \mathrm{n}-1 \\
\text { (where } \mathrm{n} \text { is the total } \\
\text { number of actors on } \\
\text { a network) }\end{array}$ \\
$\begin{array}{c}\text { Frequency that an } \\
\text { actor appears in the } \\
\text { centrality }\end{array}$ & $\begin{array}{c}\text { Of 0-1 (the closer to } \\
\text { shortest paths among } \\
\text { the actors of the } \\
\text { network. }\end{array}$ & $\begin{array}{c}\text { is the actor and the } \\
\text { closer to 0, the less } \\
\text { central is the actor) }\end{array}$ \\
\hline
\end{tabular}

Source: Adapted from Wasserman and Faust (1994)

\subsection{Statistical Analysis}

Correlation and simple linear regression were used to understand associations between centrality and the generation of innovations. Therefore, for the correlation analysis, the indicator used was the Pearson productmoment correlation coefficient or simply Pearson's correlation coefficient, which measures the relative strength of a linear relationship between two numerical variables in which the correlation coefficients range between -1 for a perfect negative correlation, and +1 for a perfect positive correlation. The higher the quality of the setting (or linear association) the closer to -1 or +1 will be the value of the coefficient $\mathrm{R}$ (Berenson, Levine and Krehbiel, 2011; Martins and Domingues, 2011).

A simple linear regression analysis was also performed, where a single independent numerical variable $\mathrm{X}$ is used to estimate the numerical dependent variable Y. The regression analysis allows to identify the type of the mathematical relationship between the dependent and independent variables and to quantify the effect of the changes that the independent variable has on the dependent variable (Berenson, Levine and Krehbiel, 2011).

The quality of the adjusted model is measured by $\mathrm{R}^{2}$, called R-squared, that describes the amount of variation in the response that is explained by the least squares line. Its value ranges from 0 to 1 (Diez, Barr and Çetinkaya-Rundel, 2012).

The linearity, nearly normal residuals and homoscedasticity of the residuals, necessary for the linear regression analysis, were tested by the scatterplots of the data and residuals plot, residuals histogram and normal probability plot of residuals (Diez, Barr and Çetinkaya Rundel, 2012).

Therefore, in order to verify the association between the generation of innovation and the position of the actors in the networks, simple linear regression analysis was used. 
As a measure for generation of innovation, the data was tested separately for each measure of centrality. The actors analyzed were Embrapa research centers and positioning measures were degree centrality and betweenness centrality.

Results are presented showing the scatterplots with the least squares lines, the equations of the regressions lines, the R-squared $\left(\mathrm{R}^{2}\right)$ and the $\mathrm{p}$-values. The equations were tested using least squares regression. For this, the opensource R statistics software combined with RStudio software was used. A 95\% confidence level was used for all tests.

\section{RESULTS AND DISCUSSION}

\subsection{Analysis of the Centrality for Embrapa Innovation Networks}

Two measurements were considered: degree centrality and betweenness centrality. These parameters were analyzed separately within the organizational patent network.

Table 1 shows the 30 Embrapa research centers and their individual measures regarding patents applications between 1980 and 2009, degree centrality and betweenness centrality.

TABLE 1 - Number of patent applications made between 1980 and 2009 and centralities of the Embrapa research centers

\begin{tabular}{|c|c|c|c|}
\hline Embrapa research centers & Patents applications & Degree centrality & Betweenness centrality \\
\hline Embrapa Instrumentation & 50 & 12 & 0.28 \\
\hline Embrapa Genetic Resources and Biotechnology & 30 & 11 & 0.28 \\
\hline Embrapa Food Technology & 28 & 7 & 0.29 \\
\hline Embrapa Southeast Livestock & 7 & 6 & 0.13 \\
\hline Embrapa Agrobiology & 8 & 5 & 0.05 \\
\hline Embrapa Tropical Agroindustry & 6 & 5 & 0.12 \\
\hline Embrapa Coffee & 3 & 5 & 0.07 \\
\hline Embrapa Goats and Sheep & 4 & 4 & 0.06 \\
\hline Embrapa Maize and Sorghum & 13 & 4 & 0.05 \\
\hline Embrapa South Livestock & 6 & 4 & 0.1 \\
\hline Embrapa Cerrados & 11 & 3 & 0.13 \\
\hline Embrapa Temperate Agriculture & 9 & 3 & 0 \\
\hline Embrapa Dairy Cattle & 8 & 3 & 0.03 \\
\hline Embrapa Environment & 9 & 3 & 0.05 \\
\hline Embrapa Soybean & 9 & 3 & 0 \\
\hline Embrapa Swine and Poultry & 3 & 3 & 0.05 \\
\hline Embrapa Cotton & 1 & 2 & 0 \\
\hline Embrapa Western Amazon & 2 & 2 & 0 \\
\hline Embrapa Eastern Amazon & 10 & 2 & 0.02 \\
\hline Embrapa Rice and Beans & 5 & 2 & 0 \\
\hline Embrapa Beef Cattle & 8 & 2 & 0.02 \\
\hline Embrapa Semi-Arid & 1 & 2 & 0 \\
\hline Embrapa Wheat & 8 & 2 & 0 \\
\hline Embrapa Vegetables & 5 & 1 & 0 \\
\hline Embrapa Pantanal & 1 & 1 & 0 \\
\hline Embrapa Acre & 1 & 0 & 0 \\
\hline Embrapa Agriculture Informatics & 1 & 0 & 0 \\
\hline Embrapa Soils & 1 & 0 & 0 \\
\hline Embrapa Coastal Tablelands & 2 & 0 & 0 \\
\hline Embrapa Grape and Wine & 2 & 0 & 0 \\
\hline
\end{tabular}

Source: Data based on INPI and CNPq 
A total of 30 Embrapa research centers, alone or together with partners, sent patent applications to INPI in the period between 1980 and 2009. The average number of patents per center was 8.4. It is important to remark that 9 of the 30 centers stood above this average.

Embrapa Instrumentation showed the highest degree centrality for organizational patent networking. As for the betweenness centrality, that unity was the second most central actor along with Embrapa Genetic Resources and Biotechnology, second only to Embrapa Food Technology. From the total of 222 patent applications assessed, Embrapa Instrumentation, alone and with partners, accounted for 50 requests, representing the Embrapa center with the largest number of patent applications in the period. Second in the ranking was Embrapa Genetic Resources and Biotechnology, with 30 applications, being also the unit with the second highest value for degree centrality and betweenness centrality.

It should be noticed that the Federal University of Rio de Janeiro (UFRJ), an important partner of Embrapa, had the third highest score for degree centrality (8) and the fourth largest value for betweenness centrality $(0.27)$. UFRJ had 6 patent applications in partnership with Embrapa research centers.
The Embrapa Food Technology had 28 patent applications individually or with partners, being the center with the third highest number of patent applications. It also held the third position among Embrapa centers for degree centrality.

Five Embrapa centers showed a zero value for degree centrality and betweenness centrality, namely, Embrapa Coastal Tablelands, Embrapa Grape and Wine, Embrapa Acre, Embrapa Agriculture Informatics and Embrapa Soils, having only one or two patent applications each. Pictures 1 and 2 clearly show the position and impact of the four institutions that reached the highest number of patents as well as the highest degree centrality and betweenness centrality.

In general, these results have shown that there is a positive relationship between network centrality and generating innovation. However, according to Björk and Magnusson (2009), centrality presents some limits. These limits are related to the argument that high quality innovative ideas can be seen as a stage function, where until a given level, high network centrality will also provide high-quality innovation, but above that level, being better connected will not necessarily be positive (Björk and Magnusson, 2009).

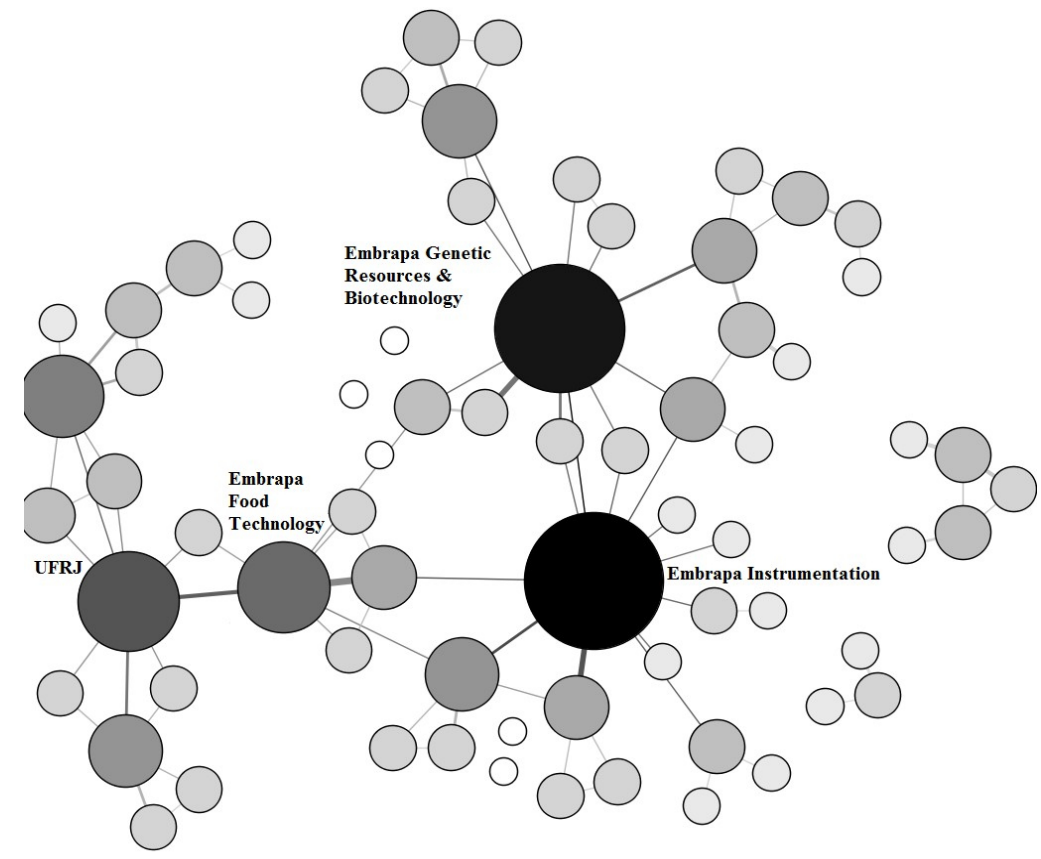

FIGURE 1 - Degree centrality for organizational patent network among Embrapa research centers and its institutional partners between 1980 and 2009

Source: Research data

Organizações Rurais \& Agroindustriais, Lavras, v. 19, n. 3, p. 192-203, 2017 


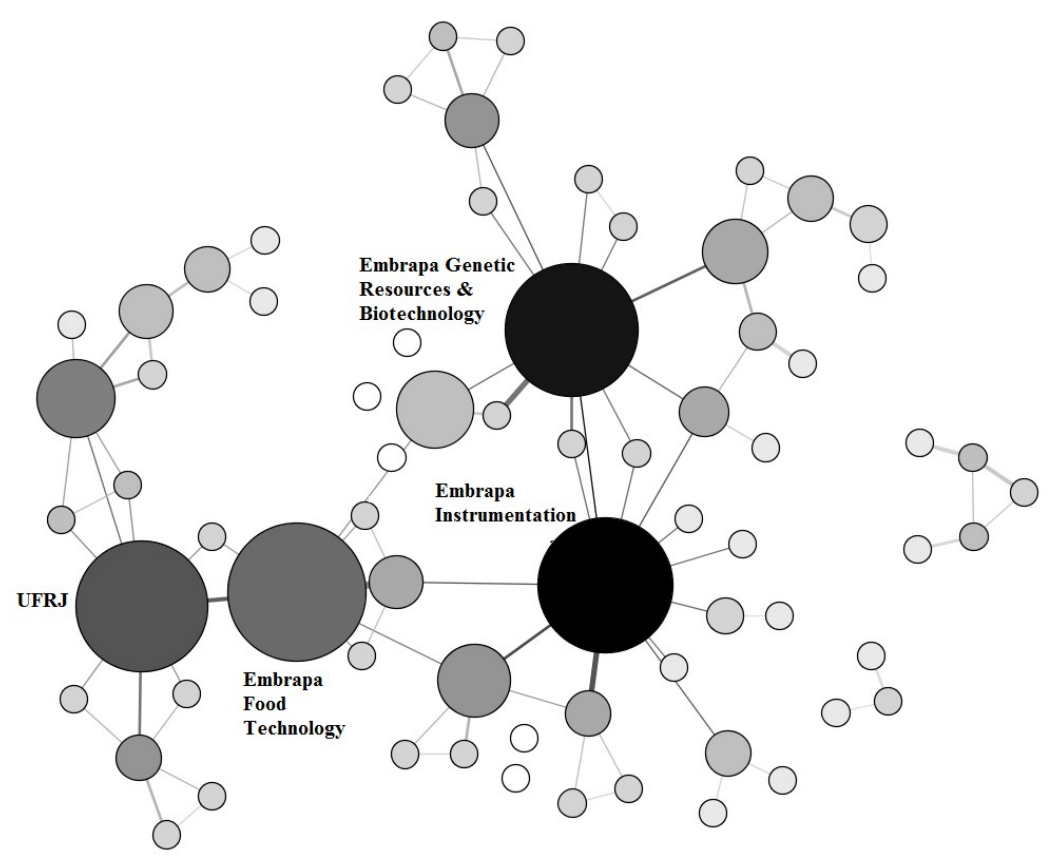

FIGURE 2 - Betweenness centrality for organizational patent network among Embrapa research centers and its institutional partners between 1980 and 2009

Source: Research data

Degree centrality and betweenness centrality are conceptually distinct, since the first measures only the number of connections one actor has and the second considers the actor as a bridge, and measures its geodesic among other actors. However, in this study it was observed that the four most central actors also reached the highest scores for both evaluations.

The four most central actors (Embrapa Instrumentation, Embrapa Genetic Resources and Biotechnology, Embrapa Food Technology and Federal University of Rio de Janeiro (UFRJ)) follow the findings from Protegerou et al. (2013) in which research centers and institutions of education have an active role on innovation networks. According to Scott (2017), these institutions are well connected to their surrounding environment and they have a central role in generating innovation.

There are indications that the centrality of the actors is contributing to innovation, as the most central actors in the network are the ones who requested the largest number of patents in the period. Thus, these actors are very important for innovation, corroborating with results from Uddin et al. (2013), in the sense that the degree of centrality positively influences innovation performance.

\subsection{Relationship Between Innovation and Centrality Measures}

Intending to have an overview of the innovation networks, the Pearson's coefficient between centrality measures and the amount of patent applications was calculated and shown in Table 2. Centrality analyzed measures included only Embrapa research centers.

TABLE 2 - Correlation between number of patent applications and centrality measures among Embrapa research centers between 1980 and 2009

\begin{tabular}{cccc}
\hline & $\begin{array}{c}\text { Number } \\
\text { of patent } \\
\text { applications }\end{array}$ & $\begin{array}{c}\text { Degree } \\
\text { centrality }\end{array}$ & $\begin{array}{c}\text { Betweenness } \\
\text { centrality }\end{array}$ \\
\hline $\begin{array}{c}\text { Number } \\
\text { of patent } \\
\text { applications } \\
\text { Degree } \\
\text { centrality }\end{array}$ & 1 & & \\
$\begin{array}{c}\text { Betweenness } \\
\text { centrality }\end{array}$ & 0.85 & 1 & \\
\hline
\end{tabular}

Source: Research data 
For Berenson, Levine and Krehbiel (2011), the correlation coefficient measures the relative strength of a linear relationship between two numerical variables in which the correlation coefficients range between -1 and +1 , corresponding to a perfect negative correlation and a perfect positive correlation respectively. Table 2 shows that both measures of centrality have a significant positive correlation to the amount of patent applications. Degree centrality had 0.856 as the greatest value, which according to Martins and Domingues (2011) indicates good correlation. With a value a slightly under 0.849 , the correlation between the number of patent applications and betweenness centrality is also high. These high correlations between the amount of patent applications and the two-centrality measures suggest that centrality can contribute to the generation of innovation.

Aiming a deeper analysis to establish a possible functional relationship between measures of centrality and innovation, a simple linear regression analysis was also performed. Its results are presented in the next section.

\subsection{Association Between Centralities and Innovation}

Figure 3 represents the scatterplot of patent applications and degree centrality.

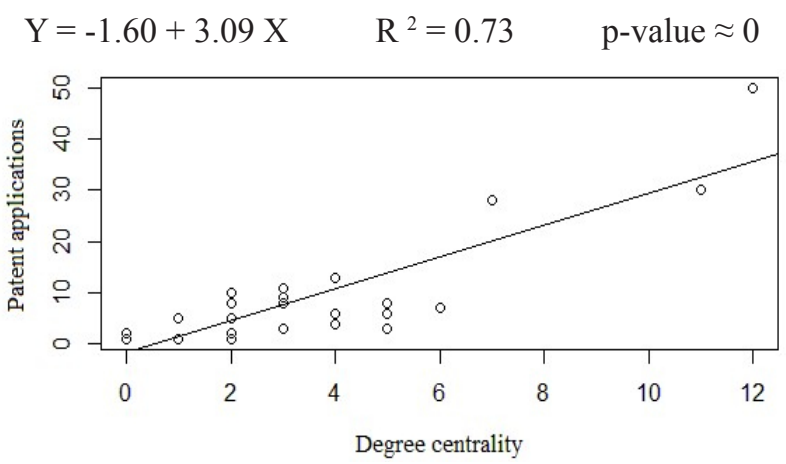

FIGURE 3 - Scatterplot of patent applications and degree centrality for Embrapa research centers between 1980 and 2009

Source: Research data

From this analysis it can be observed that $73.3 \%$ of the variability in the number of Embrapa patent applications is explained by the degree centrality. This value for the coefficient of determination indicates that the model's explanatory power is high according to Martins and Domingues (2011). As the p-value was approximately zero, it can be said that the degree centrality is a significant predictor for the number of patent applications for Embrapa centers.
The beta value was positive, reaching 3.09. This means that for each increase of one degree in degree centrality, it can be expected an average increase of 3.09 in the patent applications involving an Embrapa research center. This finding follows the same pattern as proposed by Abbasi et al. (2011), Eslami et al. (2013) and Guan et al. (2016).

Figure 4 shows the association of patent applications regarding the betweenness centrality.

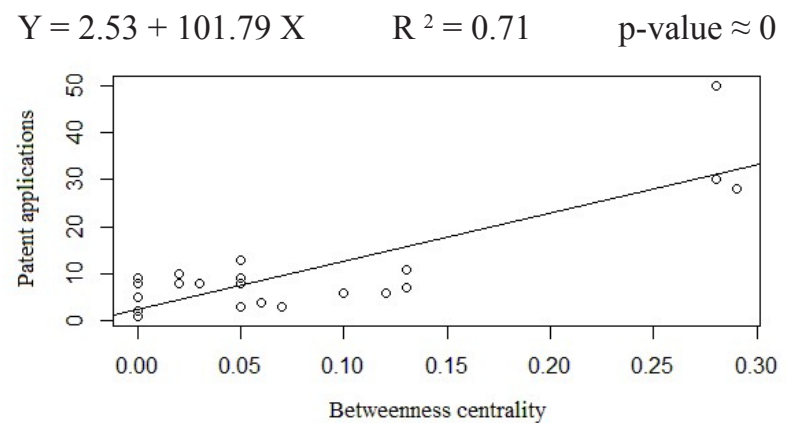

FIGURE 4 - Scatterplot of patents applications and betweenness centrality for Embrapa research centers between 1980 and 2009

Source: Research data

The betweenness centrality explains in $71 \%$ the variability in the number of Embrapa patent applications. According to Martins and Domingues (2011) this explanation power from the model is intermediate. According to Wasserman and Faust (1994), greater betweenness centrality can generate a greater control over information flow or generate control over relationships among other actors.

Since the p-value was approximately zero, it can be said that the betweenness centrality is also a significant predictor for the number of patent applications by Embrapa centers. It plays an important role for innovation on these research centers, once from the study it became clear that there is a positive and significant relationship between this measure and the number of patent applications made over the three decades analyzed.

The beta value was positive, reaching 101.79. This means that for each increase of 0.01 degree in betweenness centrality, it can be expected an average increase of 1.01 in the patent applications involving an Embrapa research center.

These results confirm the ideas defended by Yin et al., (2006), suggesting that actors with high betweenness centrality, by controlling the flow of knowledge, are of great importance for the development of new products and innovative ideas. Similar results showing the influence of 
betweenness centrality in innovation activities were also obtained by Ferriani et al. (2009), Abbasi et al. (2012) and Guan et al. (2016).

\section{CONCLUSION}

Results from this work follow the findings from Protogerou et al. (2013), Temel et al. (2013), Uddin et al. (2013), Paula (2014), Wang and Hsu (2014), Pinto et al. (2015) and Shiri et al. (2015), showing association between social network and the generation of innovations among Embrapa research centers and its partner institutions. Part of the findings from Temel et al. (2013) was not similar to results from this work. The authors found that cooperation with universities did not increase tendency to innovation, while in this work Federal University of Rio de Janeiro (UFRJ) was highlighted as one of the institutions with a central position in the whole network studied.

Results regarding degree centrality complemented the findings from Abbasi et al. (2011), Eslami et al. (2013) and Guan et al. (2016), since they show that this measure has influence on generating innovation. The same happens to betweenness centrality, where results found corroborate the findings from Ferriani et al. (2009), Abbasi et al. (2012) and Guan et al. (2016).

The results herein found show that collaboration through the innovation network studied favored innovation, generating an increase in the number of patents. As previously mentioned, the success of Brazilian agribusiness came from investments in Research, Development and Innovation (Gouvea and Kassicieh, 2012), and Embrapa's research centers, together with SNPA had a relevant role in this process (Cornell University et al., 2017), also evidenced by results of this work.

It is important to mention that the findings from this work contain relevant information for setting public policies, which can be used to avoid risks mentioned by Robertson and Langlois (1995). It is important to remark that public research institutions in Brazil are overloaded with bureaucracy. This negatively affects agility and flexibility, which are fundamental features for generating innovation. The same is true for establishing collaboration among institutions and building partnerships, especially with the private sector. Therefore, to improve networking and knowledge sharing, one of the first structural changes necessary is related to rules applying to public science and development institutions. It is necessary to facilitate purchases and contracts in order to leverage innovation as a whole and for agriculture in Brazil.
Despite an evident interest in improving collaboration to catalyze innovation, a few studies were carried out to examine the impact of collaboration on innovation in emerging economies (Temel et al., 2013). This work is a clear demonstration that a solid collaboration network in an emerging economy country significantly contributes for generating innovation.

As a limitation, the data provided evidenced a naturally occurring association between variables, but they cannot by themselves show a causal connection. Experiments are suggested to explore this relationship between variables.

The networks monitoring through measures of centrality can be considered one important management implication of this study because it can help improvement on generation of innovation by research centers. Centrality analysis can be performed periodically, improving decision-making and guiding management to a better institutional positioning towards innovation.

Case studies focusing on Embrapa research centers that show more innovation could help to better understand the reasons that led to these results and would help identifying good practices that can be adopted in other centers.

Similar studies could be carried out focusing on different and specific innovation assets such as plant varieties, software and trademarks, also including other economic sectors, in order to compare innovation network behavior.

\section{REFERENCES}

ABBASI, A.; ALTMANN, J.; HOSSAIN, L. Identifying the effects of co-authorship networks on the performance of scholars: a correlation and regression analysis of performance measures and social network analysis measures. Journal of Informetrics, New York, v. 5, n. 4, p. 594-607, 2011.

ABBASI, A.; CHUNG, K. S. K.; HOSSAIN, L. Egocentric analysis of co-autorship network structure, position and performance. Information Processing \& Management, Elmsford, v. 48, n. 4, p. 671-679, 2012.

ALVES, J. S. et al. Arranjos produtivos e inovativos locais de calçados: um estudo comparativo dos APLs de Franca/SP e Campina Grande/PB. In: SIMPÓSIO DE ENGENHARIA DE PRODUÇÃO, 2004, Bauru. Anais... Bauru: SIMPEP, 2004. 1 CD-ROM. 
BASTIAN, M.; HEYMANN, S.; JACOMY, M. Gephi: an open source software for exploring and manipulating networks. In: INTERNATIONAL CONFERENCE ON WEBLOGS AND SOCIAL MEDIA, 8., 2009, San Jose. Proceedings... San Jose: ICWSM, 2009. p. 361-362.

BERENSON, M. L.; LEVINE, D. M.; KREHBIEL, T. C. Basic business statistics: concepts and applications. Boston: Pearson, 2011.

BJÖRK, J.; MAGNUSSON, M. Where do good innovation ideas come from?: exploring the influence of network connectivity on innovation idea quality. Journal of Product Innovation Management, Chicago, v. 26, n. 6, p. $662-670,2009$.

BRASIL. Constitutional Amendment $n^{\circ}$ 85, from february 26, 2015. Brasília, DF 2015. Available from: <http://www.planalto.gov.br/ccivil_03/constituicao/ Emendas/Emc/emc85.htm>. Access in: 12 May 2015.

Law no 10.973, from december 2, 2004. Provides incentives for innovation and scientific and technological research. Brasília, DF, 2004. Available from: <http:// www.planalto.gov.br/ccivil_03/_ato2004-2006/2004/lei/ 110.973.htm $>$. Access in: 12 May 2014.

BURT, R. S. Structural holes: the social structure of competition. Cambridge: Harvard University Press, 1992.

CORNELL UNIVERSITY; INSEAD; WIPO. The global innovation index 2017: innovation feeding the world. Ithaca, 2017.

CORREA, P.; SCHMIDT, C. Public research organizations and agricultural development in brazil: how did Embrapa get it right? World Bank-Economic Premise, Washington, v. 145, p. 1-10, 2014.

DAVIS, J.; GOLDBERG, R. The genesis and evolution of agribusiness. Boston: Harvard University, 1957.

DE PELLEGRIN, I. et al. Redes de inovação: construção e gestão da cooperação pró-inovação. Revista de Administração da Universidade de São Paulo, São Paulo, v. 42, n. 3, p. 313-325, 2007.

DIEZ, D. M.; BARR, C. D.; ÇETINKAYA-RUNDEL, M. OpenIntro statistics. Durham: Create Space, 2012.
EMPRESA BRASILEIRA DE PESQUISA AGROPECUÁRIA. Secretaria de Comunicação. Embrapa em números. Brasília, DF, 2017.

ESLAMI, H.; EBADI, A.; SCHIFFAUEROVA, A. Effect of collaboration network structure on knowledge creation and technological performance: the case of biotechnology in Canada. Scientometrics, Amsterdam, v. 97, n. 1, p. 99119, 2013.

EVERETT, M. G.; BORGATTI, S. P. Extending centrality. In: CARRINGTON, P. J.; SCOTT, J.; WASSERMAN, S. (Ed.). Models and methods in social network analysis. Cambridge: Cambridge University Press, 2005. p. 2-23.

FERRIANI, S.; CATTANI, G.; BADEN-FULLER, C. The relational antecedents of project-entrepreneurship: network centrality, team composition and project performance. Research Policy, Amsterdam, v. 38, n. 10, p. 1545-1558, 2009.

FREEMAN, L. C. A set of measures of centrality based on betweenness. Sociometry, Washington, v. 40, n. 1, p. 35-41, 1977.

GIL, A. C. Como elaborar projetos de pesquisa. 4. ed. São Paulo: Atlas, 2002.

GOUVEA, R.; KASSICIEH, S. Bridging the innovation divide: the Brazilian experience. Thunderbird International Business Review, Glendale, v. 54, n. 3, p. 275-289, 2012.

GUAN, J. et al. Does country-level R\&D efficiency benefit from the collaboration network structure? Research Policy, Amsterdam, v. 5, n. 4, p. 770-784, 2016.

HANSEN, D. L.; SHNEIDERMAN, B.; SMITH, M. A. Analyzing social media networks with NodeXL: insights from a connected world. Amsterdam: M. Kaufmann, 2011.

JACKSON, M. O. Social and economic networks. Princeton: Princeton University Press, 2008.

MALERBA, F.; VONORTAS, N. S. Innovation networks in industries. Northampton: E. Elgar, 2009.

MARCONI, M. A.; LAKATOS, E. M. Fundamentos de metodologia científica. 5. ed. São Paulo: Atlas, 2003.

Organizações Rurais \& Agroindustriais, Lavras, v. 19, n. 3, p. 192-203, 2017 
MARTINS, G. A.; DOMINGUES, O. Estatística geral e aplicada. São Paulo: Atlas, 2011.

NEWMAN, M. E. Modularity and community structure in networks. Proceedings of the National Academy of Sciences of the United States of America, Washington, v. 103, n. 23, p. 8577-8582, 2006.

ORGANIZAÇÃO PARA A COOPERAÇÃO E O DESENVOLVIMENTO ECONÔMICO. Manual de Oslo: diretrizes para coleta e interpretação de dados sobre inovação. Brasília, DF: FINEP, 1997.

PAULA, N. Q. de. Redes de inovação tecnológica no agronegócio. 2014. 128 p. Dissertação (Mestrado em Administração)-Universidade Federal de Mato Grosso do Sul, Campo Grande, 2014.

PINTO, H.; NORONHA, M. T.; FAUSTINO, C. Knowledge and cooperation determinants of innovation networks: a mixed-methods approach to the case of Portugal. Journal of Technology Management Innovation, Santiago, v. 10, n. 1, p. 83-102, 2015.

PROTOGEROU, A.; CALOGHIROU, Y.; SIOKAS, E. Twenty-five years of science-industry collaboration: the emergence and evolution of policy-driven research networks across Europe. Journal of Technology Transfer, Indianapolis, v. 38, n. 6, p. 873-895, 2013.

ROBERTSON, P. L.; LANGLOIS, R. N. Innovation, networks, and vertical integration. Research Policy, Amsterdam, v. 24, p. 543-562, 1995.

ROBINS, G.; LEWIS, J. M.; WANG, P. Statistical network analysis for analyzing policy networks. Policy Studies Journal, Washington, v. 40, n. 3, p. 375-401, 2012 .

SALMON, P. M. et al. An on-road network analysis-based approach to studying driver situation awareness at rail level crossings. Accident Analysis \& Prevention, Chicago, v. 58, p. 195-205, 2013.

SCOTT, J. Social network analysis. $4^{\text {th }}$ ed. London: SAGE, 2017.
SHIRI, G.; SAUVEE, L.; ABDIRAHMAN, Z. Bridge and redundant ties in networks: the impact on innovation in food SMEs. European Journal of Innovation Management, London, v. 18, n. 3, p. 355-379, 2015.

STEINER, P. A sociologia econômica. São Paulo: Atlas, 2006.

TEMEL, S.; MENTION, A.; TORKKELI, M. The impact of cooperation on firms' innovation propensity in emerging economies. Journal of Technology Management Innovation, Santiago, v. 8, n. 1, p. 54-64, 2013.

UDDIN, S.; HOSSAIN, L.; RASMUSSEN, K. Network effects on scientific collaborations. Plos One, San Francisco, v. 8, n. 2, 2013. Available from: <http:// journals.plos.org/plosone/article?id=10.1371/journal. pone.0057546>. Access in: 10 Apr. 2016.

UNIVERSIDADE DE SÃO PAULO. Centro de Estudos Avançados em Economia Aplicada; CONFEDERAÇÃO DA AGRICULTURA E PECUÁRIA DO BRASIL. PIB do agronegócio. São Paulo, 2012. Available from: $<$ http:// www.cepea.esalq.usp.br/pib/>. Access in: 28 Apr. 2013.

WANG, C. H.; HSU, L. C. Building exploration and exploitation in the high-tech industry: the role of relationship learning. Technological Forecasting \& Social Change, New York, v. 81, p. 331-340, 2014.

WASSERMAN, S.; FAUST, K. Social network analysis: methods and applications. Cambridge: Cambridge University Press, 1994.

THE WORLD BANK. Enhancing agricultural innovation: how to go beyond the strengthening of research systems. Washington, 2006.

YAN, E.; DING, Y. Applying centrality measures to impact analysis: a coauthorship network analysis. Journal of the American Society for Information Science and Technology, Silver Spring, v. 60, n. 10, p. 2107-2118, 2009.

YIN, L. C. et al. Connection and stratification in research collaboration: an analysis of the COLLNET network. Information Processing Management, Greenburgh, v. 42, n. 6, p. 1599-1613, 2006. 